\title{
茶の仕上用振動ふるいの最適操作条件
}

農林水産省茶業試験場

中田典男・原利男

\section{Operating Condition of Vibrating Screen for Tea Refining}

\author{
By Norio Nakada and Toshio HaRA \\ National Research Institute of Tea
}

\section{1 ま か がき}

著者の一人原は，さきに茶の仕上工程の基本操作であ る，茶のふるい分けを解明するために，回分式の平面ら るい（業界では平行ふるいと呼んでいるもの）の振幅と 振動数との関係を調べ, 最適振動条件は遠心効果 $\mathrm{K}=1.3$ 〜1.7であることを報告した。

その後，業界ではローヘッド型スクリージを改良した 振動ふるいが，茶の任上用ふるい分け機として開発され， 茶の仕上用総合機のふるいとして普及してきた。振動ふ るいは遠心効果 $\mathrm{K}=4$ 以上の振動条件であるため, ふる いの目詰りが少なく，流れ作業に適しているので，粉体 のふるい分けに多く使用されている。

前荣のように粒子が大きく，細長いすのに，振幅の小 さい振動ふるいを使用すると，ふるい分け中に粒子の立 つ確率が少なく，細長い粒子の泉るい分けが少なくなる のではないかと考兄られる。そこで，今回は茶のふるい 分けに使用されている振動方るいの最適振動条件と，心 るい分け特性及び使用法等について検討し，茶のふるい 分け機として性能のよいことを認めたので，ここにとり まとめて報告する。

\section{2 試 験 方 法}

\section{1 振動ふるいの最適振動条件の調査}

㧐幅 $30 \mathrm{~mm}$, 振動数を 400 600 rpm 汇可変できる回
分式の実験用の振動装置（ふるい網面に直角方向の往復 運動をする）に，JIS 標準ふるいを取付け，振動条件（遠 心效果）とふるい下量との関係を調べた。調查はふるい 目の開き才法 $1.68 \mathrm{~mm}$ と $2.00 \mathrm{~mm}$ の JIS 標準ふるい （径 $200 \mathrm{~mm}$ ）を用い，50 $\mathrm{g}$ の茶を 30 秒から 5 分間をで ふるい分けて，ふるい下量を測定し，罢積\%で示した。

\section{2 茶のふるい分けにおける振動ふるいと平面ふる}

\section{いの基本特性}

振動あるいは前記 2.1 と同様の振動装置飞, ふるい目 の閒さ法 $2.00 \mathrm{~mm} の \mathrm{JIS}$ 標準らるいを取付け, 茶の 仕上用総合機のふるいと同じ振動数 $500 \mathrm{rpm}$ (橾心効果 $\mathrm{K}=4$ ，2）て茶のふるい分けを行った。

平面ふるいは網面に平行な往復運動をする実験装置

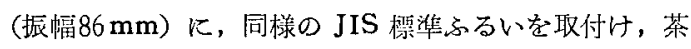
の仕上用平面ふるいと同様の振動数 $180 \mathrm{rpm}$ (遠心効果 $\mathbf{K}=1.6$ ）で茶のふるい分けを行い，30秒から 5 分間をで のふるい下累積\%を求めた。

\section{3 茶の仕上用振動ふるいの特性調查}

茶の仕上用総合㙨に使用されている振動ふるいは，図 1 亿略図を示したように，ふるい面が水平に対して $45^{\circ}$ の上下運動を行い, 振幅 $30 \mathrm{~mm}$, 振動数 $500 \mathrm{rpm}$ (遠心 効果 $K=4.2$ ）でふるい分けを行い，ふるい分け中に茶を 多く立たせるようにすることと，ふるい分け時間を長く するために，茶の流れを制御するダンパ (damper) を 取付故てある。まふふるいの目詰りを防止して連続の

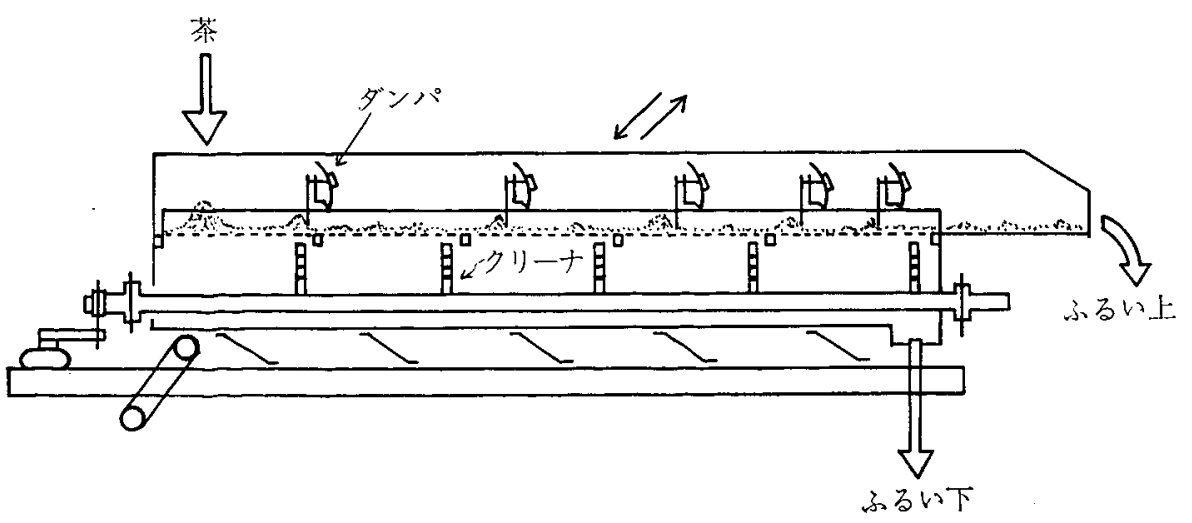

図 1 茶の仕上用振動らるい（略図） 
ふるい分けを行らため，網面の下部をかき取るクリ一 ナが装着されている。

開查は $10 \mathrm{~kg}$ また $15 \mathrm{~kg}$ の荒茶 (二番茶)を供試材料 として，茶のふるい分けに及悟すダンパ及びクリーナの 影響を調べた。ふるい網は業界で10号と呼ぶ寸メッシュ （1寸の閒にふるい目が10個あるるの）使用し, 網面 の長さは $1.3 \mathrm{~m}$, 愊は0.6 $\mathrm{m}$ ののを装着して, 茶のふる い分けを行い，ふるい下量，目詰り粒子の量等を調べた。

\section{4 茶の仕上用振動ふるいと平面ふるいの比較}

比較の対照として, 徒来から茶のふるい行けに使用さ れた，振湢 $90 \mathrm{~mm}$ ，振動数 $180 \mathrm{rpm}$ の平面らるいを用 い, 内径 $0.6 \mathrm{~m}$ の円形のらるいに $2 \mathrm{~kg}$ の荒茶（二番茶） を投入して，90秒ふるい分けを行い，ふるい下量と目詰 り粒子量を求めた。ふるい分け垁間を90秒としたのは，

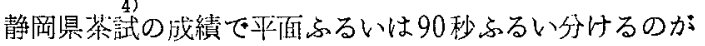
標集のように派告されているのでこれを基準とした。
振動ふるいは前記 2.3 と同様で，10 kg の茶をダンパ を直角の状態（茶の粒子が多く圤つ状態）にして，ふる い分けを行った。ふるい目は振動ふるいでオッシュの 10 㤐，平面ふるいは寸メッシュの10号と11号を使用した。 平面ふるいて 11号のふるい目を使用したのは，静岡県茶 試の成績で，振動ふるいは平面ふるいよりも1号大きい らるい目（号数の1つ少ないるの）存使用したはらがよ いと報告されている。従って，振動ふるいの10号のふる い下量と, 平面ふるいの11号のるのとを比較するために 使用した。両機の操作条件を表 1 に示した。

\section{3 試験結果及び考察}

\section{1 振動ふるいの最適振動条件}

振動ふるいの振動条件とふるい下量との関係について 调查した結果は表 20 と扣りで，遠心効果 $\mathrm{K}=3.6 \sim 5.7$ のふるい下字が他のものより少し多く, 最適条件がこの

表 1 举の仕上用ふるい分け機の操作条件

\begin{tabular}{|c|c|c|c|c|}
\hline 種 & 全振幅 & 振 動 数 & 還心効果 & ふるい面の大きさ \\
\hline 振動らるい & ${ }_{30}^{\mathrm{mm}}$ & $\begin{array}{l}\text { rpm } \\
500\end{array}$ & 4.20 & 長さ 1.29 , 幅 $0.58 \mathrm{~m}$ \\
\hline 平面るるい & 90 & 180 & 1.63 & 内径 $0.58 \mathrm{~m}$ \\
\hline
\end{tabular}

装 2 振動ふるいの振動条件に関する調查結果（ふるい目 $1.68 \mathrm{~mm}$ )

\begin{tabular}{|c|c|c|c|c|c|c|c|}
\hline \multirow{2}{*}{$\begin{array}{c}\text { 振 動 数 } \\
(\mathrm{rpm})\end{array}$} & \multirow{2}{*}{$\begin{array}{c}\text { 遠心效果 } \\
\text { (K) }\end{array}$} & \multicolumn{6}{|c|}{ ふるい下 (\%) } \\
\hline & & $30 \mathrm{sec}$ & $1 \mathrm{~min}$ & $2 \mathrm{~min}$ & $3 \mathrm{~min}$ & $4 \mathrm{~min}$ & $5 \mathrm{~min}$ \\
\hline 400 & 2.69 & 25.6 & 34.2 & 43.8 & 48.3 & 50.2 & 52.2 \\
\hline 460 & 3.55 & 27.0 & 36.4 & 45.2 & 49.8 & 51.8 & 53.8 \\
\hline 520 & 4.54 & 26.0 & 36.4 & 45.4 & 49.8 & 51.6 & 53.8 \\
\hline 580 & 5.65 & 26.2 & 36.6 & 45.8 & 48.8 & 51.2 & 53.4 \\
\hline 610 & 6.25 & 23.2 & 31.6 & 41.4 & 40.8 & 43.2 & 43.6 \\
\hline
\end{tabular}

籁囲にあることが認められた。なた，多くの粉粒体のふ るい分けには遠心効果 $\mathrm{K}=3 \sim 6$ の振動条件が採用され ているようで，茶のふるい分け機る粉粒体の振動条件之 全く一致した。

ここでいう遠心効果とは, 振動の最大加速度と重力の 加速度の比をいい，次式で示される。

$$
\begin{array}{rll}
\text { 遠心効果 } & \mathrm{K}=\frac{\mathbf{r} \omega^{2}}{\mathrm{~g}} & \\
\text { たたし }, & \mathrm{r}: \text { 片振幅 } & (\mathrm{cm}) \\
& \omega: \text { 振動の角速度 } & (\mathrm{radian} / \mathrm{sec}) \\
& \mathrm{g}: \text { 重力の加速度 } & 980\left(\mathrm{~cm} / \mathrm{sec}^{2}\right)
\end{array}
$$

この值は振動ふるいの基本特性值で, ふるい網上の粒 子の運動を推定できるし，機械の材料強度や，ベアリン グ強度の計算にも使用する大切な值である。

\section{2 茶のふるい分けにおける振動ふるいと平面ふる いの基本特性}

振動らるいと平面らるいの茶らるい分け特性を明らか
にするため，回分式の実験装置で，ふるい分け時間に伴 5ふるい下量の変化を調べた結果は図 20 と招りであ る。これによると，振動ふるいの㴒 5が平面ふるいより， ふるい下量が少し少なくなることが認められた。

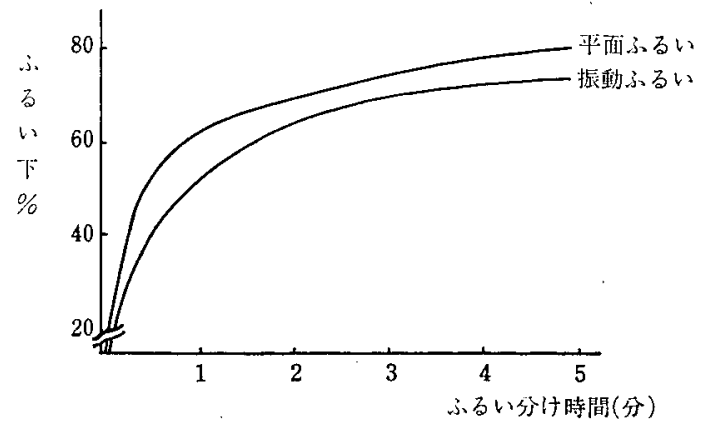

図2 茶のふるい分けに拈ける振動ふるいと平面 ふるいの基本特性（ふるい目 $2.00 \mathrm{~mm}$ ) 
これは，茶のよ5に粒子が大きく細長いるのは，振幅 の小さいふるいを使用すると，ふるい分け中に粒子の立 つ確率が少なくなり，大きな細長い粒子のふるい分けが 少なくなるのではないかと考劣る。従って、この結果か ら静岡県茶試の報告にあるょ5に，振動ふるいは平面ふ るいより，1つ号数の小さいふるい目（ふるい目の大き いるの）を使用した涪うがよいように認められた。

しかし，この実験で使用した網面に直角の上下運動を する振動ふるいは，実用機としては使用されていない。 実用機は連続してふるい分けを行らため，図1のよ5な $45^{\circ}$ の上下運動をするので，この結果をそのま適用す るのは危険であるが，振動ふるい《ついては振幅が小さ いので, 茶のよ5な粒形のるのには基本的にこの傾向は 認められるるのと考える。

\section{3 茶の仕上用振動ふるいの特性調查}

茶の仕上用振動ふるいを用い，茶の流れを調節するダ ンパのふるい分けに及漂す影響を調べた結果は表 3 のと 招りで，ふるい分けに及活すダンパの影響が大きく，ダ ンパを有効に使用することによって，ふるい下量は約 1.5 倍に増加した。

これは，ダンパによって茶の流机を調節して，ふるいい 分け時間を長くすることができることと，ダンパの部分 で茶の流れにうず現象が起り，茶の立つ確率が多く なるからふるい下量が多くなるすのと推定される。従っ て，ダンパが有効に働くよ5にその角度を調整すれば， 振動ふるいも平面ふるいと同様のふるい下量が得られる るのと考光る。

つぎに，目詰りを防止するクリーナのふるい分けに及 情す影響を調べた結果は表 4 のと括りで, 実験に使用し た茶の量が少なかったためか，クリーナのふるい下量に 及涗す影響は活とんど認められなかった。しかし，ふる
表 3 ふるるい分けに及ぼすダンパの影響

\begin{tabular}{|c|c|c|c|}
\hline 区 & 別 & ふるい下兄 & 所要時間 \\
\hline \multicolumn{2}{|c|}{ ダンパなし } & 45.5 & 1 分 45 秒 \\
\hline$"$ & 1 個 & 61.0 & 2 分 20 秒 \\
\hline$"$ & 5 個 & 66.9 & 3 分 \\
\hline
\end{tabular}

注：ふるい目 10 号，投入量 $10 \mathrm{~kg}$

表 4 ふるい分に及活すクリーナの影響

\begin{tabular}{|c|c|c|c|}
\hline 区 & $\begin{array}{c}\text { らるW下 } \\
(\%)\end{array}$ & 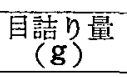 & 所要時間 \\
\hline クリーナなし & 66.6 & 107 & 4 分 45 秒 \\
\hline " 有 & 65.9 & 70 & 4 分50秒 \\
\hline
\end{tabular}

注：ふるい目 10 号，投入量 $15 \mathrm{~kg}$

い分け後に網に付着する目詰り粒子の量は，クリーナを 使用したすののほうが少なかった。従って，連続して多 量の茶をふるい分ける場合には, クリーナもその效果が 大きい上5亿考光る。

\section{4茶の仕上用振動ふるいと平面ふるいの比較}

茶のふるい分け機として伝統的に使用された平面ふる いを用い，90秒ふるい分けたらるい下量と目詰り粒子量 を対照として，ダンパを直角に調節した振動ふるいのそ れら測定值を比較した結果は表 5 のとおりである。

これによると，ダンパをよく調整した振動ふるいは， 平面ふるいとほ活同じ量のふるい下が得られ，目詰り粒 子が平面ふるいより少ないことが認められた。

以上の結果から，茶の仕上用振動ふるい性ダンパを調 整することによって，従来から使用された平面ふるいと 医活同じ量のふるい下が得られ，ふるいの目詰りが少な いので，連続作業に適したふるい分け機と認められた。

表 52 種の茶の仕上用ふるい分け機のふるい分け成續

\begin{tabular}{|c|c|c|c|c|}
\hline 区 & ふるい目 & ふるい下（\%) & 目詰り & ふるい $1 \mathrm{~m}^{2}$ 当り目詰褁 \\
\hline 振動らるい (1 & 10 号 & 72.1 & 0.5 & $63.5 \mathrm{~g}$ \\
\hline$"$ & 10 号 & 72.2 & 0.6 & 77.0 \\
\hline 平面㣻るい & 10 号 & 73.0 & 1.1 & 80.8 \\
\hline 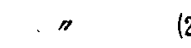 & 11 号 & 65.8 & 1.8 & 138.5 \\
\hline
\end{tabular}

\section{4 要約}

茶のふるい分けに使用されている振勳ふるいの最適振 動条件, ふるい分け特性及び使用法等について調查し, 次の知見を得た。

(1) 茶の仕上用振動ふるいの最適振動条件は，遠心効

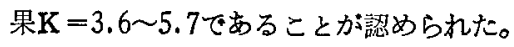

（2）茶の仕上用振動ふるいは，茶の流れを調節するダ ンパのふるい份けに及惊す影響が大きく，ダンパを有勃
に㗢くように調整すれば，従来から使用された平面らる いとほ深同じ量のふるい下が得られ，ふるいの目詰りが 少ないので，連続作業に適したふるい分け機と認められ た。

\section{5 引用 文 献}

1）原利男，久保田悦郎：茶技研， No. $19 ， 69 \sim 73$ (1958).

2）三輪茂雄：粉体のフルイ分け，日刊工業新聞社， 
p. 268 (1965).

3）三輪茂雄：ふるるい分け読本，産業技術センター， p. 151,332 (1974).

4）增沢武雄：新しい技術（農林水産省農林水産技術会 議事務局編）第16集，151 157（1978）.

(Feb. 5, 1985) 